日臨外会誌 $65(1), 161-163,2004$

症例

大動脈周囲リンパ節再発巣切除により長期生存した右側横行結腸癌の 1 例

$$
\begin{aligned}
& \text { 羽島市民病院外科, 岐皁大学第 } 1 \text { 外科* } \\
& \text { 立山健一郎二村直樹安村幹央 } \\
& \text { 丸井努松友将純関野考史* }
\end{aligned}
$$

症例は66歳の男性.1999年6月11日に右側横行結腸癌で結腸右半切除術を施行した。 術前高かったCEA は術後 1 カ月で正常化した。以後，3カ月ごとの採血および腹部 US で経過観察していたが, 腫瘍マーカーの上昇は認めず再発の徴候はなかった。2000年 4 月に施行した腹部US および CT 検查で，大動脈と下大静脈間に左腎静脈を巻き込むよ うに腫韵を認め，大動脈周囲リンパ節転移と㟝断した，上部下部消化管内視鏡検査で異 常なく, 各種画像所見で多喴器転移は認めなかった。限局した大動脈周囲リンパ節再発 と診断して同年 5 月 22 日大動脈周囲リンパ節郭清術を施行し第14病日に退院した．以後 良好な QOL が維持された。再手術後 2 年 6 力月後に上腸間膜動脈根部リンパ節に再発 を認めたが, 初回手術から約 4 年経過して担癌生存中である. 大腸癌の大動脈周囲リン ハ節転移再発に対しての外科的切除を行い，良好なQOL 維持が得られた症例を経験し たので報告する．

索引用語：結腸癌, 大動脈周囲リンパ節転移, リンバ節郭清

緒 言

大動脈周囲リンパ節転移を認める大腸癌は予後不良 なことが多く，手術による根治性は低い。とくに右側 結腸癌では大動脈周囲リンパ節郭清を行うことは稀で ある. 今回われわれは, 右側横行結腸癌術後 1 年で大 動脈周囲リンパ節転移再発をきたした症例に対して, リンパ節郭清を施行後約 2 年 6 力月間良好な経過を得 られた症例を経験したので報告する。

症 例

患者: 66歳, 男性.

現病歴：1999年 6 月11日, 右侧横行結腸癌に対して D3郭清を伴う結腸右半切除術を施行した. 大腸癌取扱 い規約では, 高分化腺癌, ss, 1 群に 2 個, 2 群に 1 個 の転移を認め, n2(十) $3 / 15$, ly2, v0, stage IIIbであ った. 術前の腹部 CT では大動脈周囲リンパ節の腫大 は証めなかった（図 1). 術後にCEA は正常化し, 外 来にて3カ月ごとの血液検查わよび腹部USを行い経 過観察していた.2000年 4 月の腹部 US で異常を認め,

2003年10月28日受付 2003年11月19日採用

〈所属施設住所〉

$\overline{\mathbf{T}} 501-6206$ 羽島市新生町 $3-246$
同月施行した腹部 CT で左腎静脈の高さを中心にして 大動脈と下大静脈間に数珠状に連なった大動脈周囲リ ンパ節転移を認めた(図 2)，肝肺放よび上部下部消化 管検查で他に転移再発はなく，患者に告知した結果， 手術を希望し，5月19日入院した.

入院時検查所見：CEA は1999年 6 月 (初回手術前) は $19.9 \mathrm{ng} / \mathrm{ml}$ と高值であったが, 街後33病日には 1.0 $\mathrm{ng} / \mathrm{ml}$ と正常範囲まで低下し，2000年 5 月（2 回目手 術前）も $0.8 \mathrm{ng} / \mathrm{ml}$ と上昇は認めなかった。

手術所見：初回手術加ら約11力月後の同年 5 月 22 日 に大動脈周囲リンパ節郭清術を施行した。転移リンパ 節は胃癌取扱い規約の16a2inter，preに該当し，左腎 静脈，下大静脈および右腎動脈に強固に瘑者していた。 このリンパ節を含め上腸間膜動脈根部から下腸間膜動 脈根部までの大動脈周囲リンパ節を郭清した（図 3 , $4)$. 手術時間は 5 時間20分, 出血量は $1,300 \mathrm{~g}$, 無輸血 であった。

病理検查所見：一塊として摘出したリンパ節（胃癌 取扱い規約上16a2リンパ節）に転移を認めた。同時に 郭清した胃癌取扱い規約上の16a2latero，16blinter，

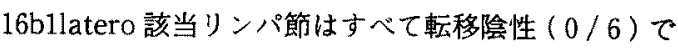
あった。 


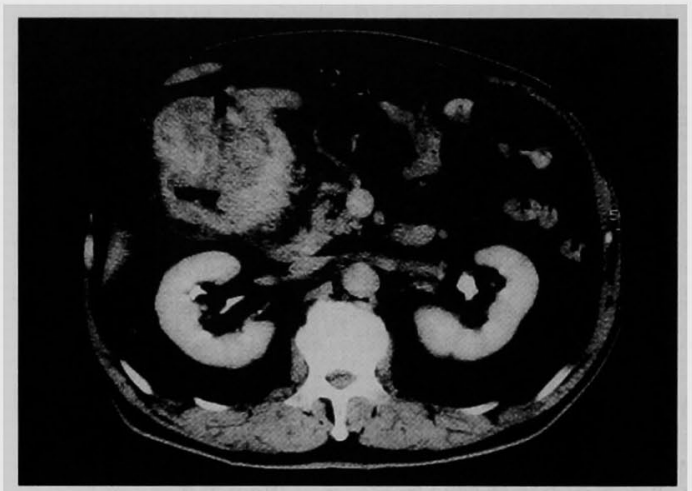

図 1 腹部 CT 検査 (初回手術前)：右側横行結腸に腫瘤 を認めるが, 大動脈周囲リンパ節腫大は認めなかった。

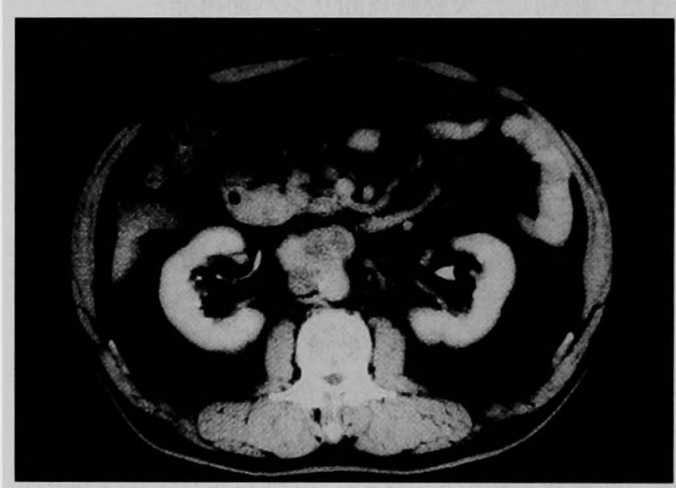

図 2 腹部 ( $\mathrm{T}$ 検查 (初回手術10力月後)：大動脈と下大 静脈間に数珠状に連なった大動脈周囲リンパ節転移を 認めた。

術後経過：術後 2 病日から数日間, 頻回の下痱を認 めたが軽快し, 術後14病日に軽快退院した. 外来で1$\mathrm{LV}$ (Levofolinate) +5-FU (5-Fluorouracil) 療法を 3 クール施行し, 現在 UFT $400 \mathrm{mg} /$ day の内服を継続 している. 初回手術後 3 年 6 力月, 再手術後 2 年 6 力 月で上腸間膜動脈根部リンパ節再発を認めたが担癌生 存中である。

\section{考 察}

大腸癌手術例における大動脈周囲リンパ節転移頻度 は $3 \%$ 強で, 右側結腸癌においても同頻度である ${ }^{122) . ~}$ しかし同時に肝転移，腹膜播種を伴うことが多く，根 治術の対象とはならず予後不良である。ささらに右側結 腸ではリンパ流が複雑であり広範囲のリンパ節郭清に 意義はないとする報告もある ${ }^{31}$. 大動脈周囲リンパ節 郭清による予後の改善は S 状結腸癌216番転移陽性例

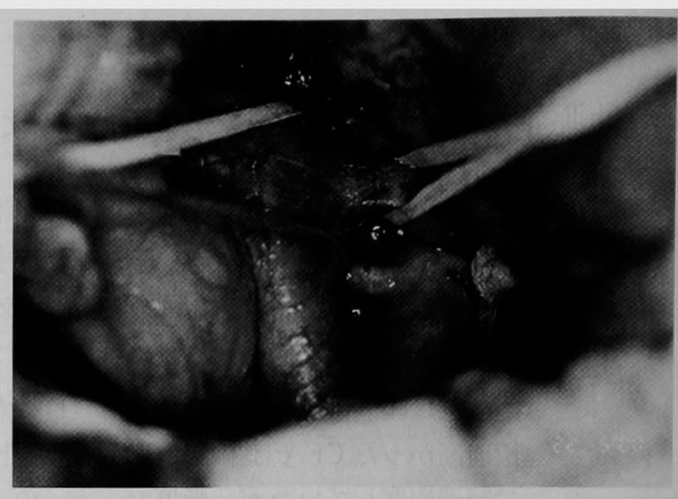

图 3 術中写真（リン八゙節郭清後）：左堅静脈，下大静脈 および右腎動脈から転移リンパ節を别離して郭清した。

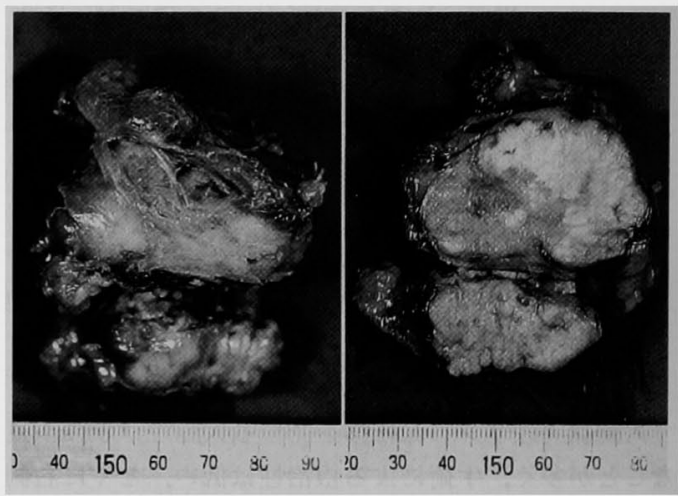

図 4 摘出標本：大動脈周囲リンパ節（胃癌取扱い規約の 16a2inter, preに該当)は神経叢と一塊となっていた (左)。割面は黄白色から灰白色で一部に隔壁を認めた (右).

のみ認められるというアンケート調査結果が報告され ており，右側結腸癌での系統的な大動脈周囲リンパ節 郭清の適応はないとされている4).S 状結腸癌および直 腸癌では大動脈周囲リンパ節転移陽性例に対しリンパ 節郭清した症例の 5 年生存例の報告が散見され $ろ^{5)-8)}$.これに対して右側結腸癌における大動脈周曲 リンパ節転移の郭清を行った詳細な報告例は 3 例のみ で, 術後15力月，16力月，3 年11力月の経過観察であ

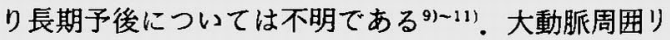
ンパ節転移に化学療法が著効した報告もあるが長期予 後に大きな期待は出来ないのが現状である ${ }^{12)}$. 森ら ${ }^{13)}$ は，高度進行大腸癌で高度りンパ節転移を認めた症例 では，手術的な治療は転移リンパ節の可及的摘出にと どめ集学的治療を組み合わせて患者にとって快適な余 
命を確保すべきであると述べており，手術適応となる 症例を見極めることが大切である，本症例では限局し た再発であり切除可能と判断して手術を選択したが, 再手術後 2 年 6 力月で腸間膜動脈周囲にリンパ節再 発をきたしており予後の改善が得られるかは疑問であ る.しかし再発に対して化学療法のみでは治療効果を 得られた可能性は低いと思われ, 再手術後長期に良好 なQOL が維持できたことから手術は有効な選択であ ったと考えられた。

また，本症例では初回手術前に高値を示したCEA は術後に正常化し, US, CT ての再発発見時にも再上 界しなかった，大腸癌術後の経過観察において画像診 断の重要性を再確認した貴重な症例として報告した。

\section{文献}

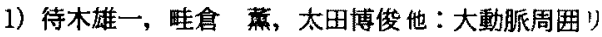
ン八゚節転移症例の検討一とくに S 状結腸癌 Skip 転移について一。 日外会誌 $91 ： 844-850,1990$

2）上野雅資, 高橋 苸, 太田博俊他：大腸癌に招け る大動脈周囲リンパ節郭清.手術 $50: 501-508$, 1996

3）阪椇, 森谷宜皓, 赤須孝之他：結腸癌におけ る大動眼周囲リンパ節 (D4) 郭清. 手術 $54: 1507$ $-1513,2000$

4）正木忠彦，武藤徽一郎，安富正幸：大動脈周囲リ ンパ節転移の実態 第44回大腸潞研究会アンケー 卜調査報告. 日本大腸肛門病会誌 $50: 318-330$, 1997
5）馬場秀文，田中克典，菅 重尚他：Virchow なら びに腹部大動脈周囲リンパ節に転移を有したS 状結腸癌手術後 6 年無再発生存の 1 例. 日消外会 誌 31: 1907-1911，1998

6）高田 実, 森田高行, 藤田美芳他：S 状結腸癌術後 の大動脈周囲リンパ節再発を切除後長期生存して いる 1 例. 日臨外会誌 $62: 2237-2240,2001$

7）中川英刀, 吉川宣煇，柳生俊夫他：左側結腸癌 直腸㙏における大動脈周囲リン八゚節轱移の梌討。 日消外会誌 $29: 2122-2126,1996$

8）金子哲也，寺部啓介，伊藤公一他：長期生存をえ たCA19-9産生進行直腸渴の 1 例. 日消外会誌 28: 1962-1966, 1995

9）春日井貴雄，片岡 誠，田中宏紀他：横行結腸癌 術後大動脈周囲リンパ節再発に対しリンパ節郭清 を行った 1 例。日臨外会誌 $59: 1585-1587,1998$

10）村川力彦, 西山 徹, 福良留宏他：大動脈周团》 ンバ節への跳霍転移を認めた横行結腸癌の 1 例. 日臨外会誌 $62: 457-460,2001$

11）山田英貴, 金井道夫, 溜口 桂：サルコイドーシ スに合併したVirchow 転移を伴う横行結腸癌の 1 切除例. 日消外会誌 $35: 1713-1716,2002$

12）川崎誠康, 藤田益嗣, 柴田純祐他: 少量 CPT-11外 来投与により著効を示した大動脈周囲りンパ節転 移を有する大腸癌の1例。癌と化療 $29: 949$ 953, 2002

13）森 武生, 高㰌慶一, 大植雅之他：高度進行大腸 癌治療の最前線 高度リンパ節転移症例に対する 郭清。消外 $24: 1335-1340,2001$

\title{
A CASE OF SURGICAL TREATMENT FOR PARA-AORTIC LYMPH NODE RECURRENCE AFTER OPERATION FOR CANCER OF THE TRANSVERSE COLON WITH RESULTANT GOOD QOL
}

\author{
Ken-ichiro TATEYAMA, Naoki FUTAMURA, Mikio YASUMURA, \\ Tsutomu MARUI, Masasumi MATSUTOMO and Takafumi SEKINO* \\ Department of Surgery, Hashima City Hospital \\ *First Department of Surgery, Gifu University School of Medicine
}

A 66-year-old man who underwent a right hemicolectomy for cancer of the transverse colon on June 111999 became to have normalized CEA level, which had been elevated before surgery, in one month after the operation. Thereafter, the rise of the tumor marker was not admitted though the followup survey was done by collecting blood and ultrasonography (US) every three months and there were no symptoms of the recurrence. A tumor was admitted to roll the left renal vein between the aorta and inferior vena cava by abdominal US and abdominal CT in April, 2000 and it was diagnosed as para-aortic lymph node metastasis. There was no evidence of another metastasis on close exploration. Para-aortic lymph node dissection was performed on May 22, 2000 and the patient was discharged from the hospital on the 14 day after the operation. Excellent QOL thereafter was maintained. As of 2 years 6 months after the reoperation, the patient experienced superior mesenteric lymph node metastasis, but remains alive as of 4 year after the first operation. Because surgical treatment for para-aortic lymph node metastasis of colon cancer resulted in excellent QOL maintenance for the patient we report the case in detail. 